\title{
A FURTHER STUDY OF THE BUTTERFLY MANIOLA JURTINA IN RELATION TO NATURAL SELECTION BY APANTELES TETRICUS
}

\author{
W. H. DOWDESWELL \\ Biology Department, Winchester College
}

\section{INTRODUCTION}

Received 9.ii.62

IN a previous account (Dowdeswell, I96I) I have provided evidence suggesting that the Braconid Apanteles tetricus may play a major part in controlling the number of spots (ranging from o to 5) on the underside of the hind wings of the female Meadow Brown butterfly, Maniola jurtina. This is a characteristic well known to be subject to the action of natural selection, the frequency of spotting assuming a variety of equilibria in different parts of Britain and elsewhere (Creed et al., 1959). Parasitisation takes place in the early larval stage, probably during the first instar. When wild larvæ are collected and reared it is found that those destined to give rise to the earliest female imagines, emerging during June, have mostly escaped infection. The resulting adults are highly spotted. Those appearing later from July to September, are derived from larvæ which have been subjected to drastic elimination by Apanteles. They are characterised by lower spot values resembling those of their free-flying counterparts. The investigations on which these results are based were conducted for four years exclusively at Middleton East, a small area of natural chalk downland situated within Harewood Forest, about $2 \frac{1}{2}$ miles from Andover (Hampshire). Clearly, it was desirable that the work should be repeated in another locality under circumstances differing as much as possible from those obtaining at Middleton, in order to establish that selective parasitism by Apanteles is not merely a local phenomenon but one of widespread occurrence.

The purpose of this paper is to describe work carried out in 1961 at Cheesefoot Head ( $4 \mathrm{I} / 532276)$; a magnificent stretch of agricultural chalk grassland situated about 3 miles S.E. of Winchester and some 14 miles from Middleton. The two localities differ from one another in several ways. While both are essentially chalk downland, the Middleton area is ungrazed, relatively flat and isolated within an extensive forest. By contrast, Cheesefoot Head is heavily grazed, steeply sloping and part of a great expanse of agricultural land stretching for many miles.

\section{REARING OF WILD LARVF}

As on previous occasions, the larvæ were collected at night by sweeping with a net. By the time of our first visit on 26th April they 
were already feeding actively and many were more than half grown. Evidently, they were at least a fortnight in advance of previous years at Middleton. The larvæ were reared in breeding cylinders and fed exclusively on grass (Sutton's Putting Green Mixture No. 25)* grown in 5 -inch pots on sterilised John Innes potting compost-a maximum of 25 larvæ per pot. The results are summarised in table $\mathrm{I}$.

Compared with previous years, the overall mortality among the larvæ proved to be about the same. However, there were significant changes in the behaviour of Apanteles. Not only was its level of incidence about Io per cent. lower than at Middleton, but its appearance in force occurred almost exactly a month later. As we shall see (p. $\left.5^{16}\right)$ these factors might account for the abnormally high spotting of the females flying at Cheesefoot Head during June and July.

TABLE I

Mortality among reared M. jurtina from Cheesefoot Head, rg6r

\begin{tabular}{|c|c|c|c|c|}
\hline $\begin{array}{c}\text { Period when } \\
\text { larvæ were } \\
\text { collected }\end{array}$ & Larvæ & $\begin{array}{c}\text { Mortality of } \\
\text { larvæ (per } \\
\text { cent.) }\end{array}$ & $\begin{array}{c}\text { Per cent. of } \\
\text { mortality due } \\
\text { to Apanteles }\end{array}$ & $\begin{array}{c}\text { Mortality of } \\
\text { pupæ (per } \\
\text { cent.) }\end{array}$ \\
\hline 26.iv-27.vi & 606 & 9.4 & 3.5 & 19.6 \\
28.vi-5.viii & 335 & 38.5 & 60.6 & \\
\hline
\end{tabular}

The large numbers of larvæ at our disposal enabled us to analyse the causes of death in more detail than had previously been possible. These were found to fall into two distinct categories.

(a) Parasitisation by Apanteles. This was accompanied by all the usual symptoms. The larvæ appeared perfectly healthy, and their behaviour when fully grown was normal except that they tended to lose the capacity to curl up when alarmed. Once the parasites had emerged and formed their characteristic white cocoons, the host frequently continued to live for several days. During this time the larva retained its green colour, turning black only after death had occurred. Parasitism by Apanteles seems always to be fatal.

(b) Infection by micro-organisms. This may take place at any stage in development, the characteristic symptoms being that the larva starts to turn black (frequently at the posterior end first) before death, which invariably occurs a few hours later. Available evidence suggests that this condition is not caused by a virus, nor is there any sign of fungal mycelia. Dr H. M. Darlow of the Microbiological Research Establishment, Porton, has examined a number of dead larvæ and isolated Escherichia (Bacterium) coli, another Gram-positive rod, and a Gram-positive coccus. None of these is identifiable with known

* This consists of 25 per cent. Agrostis tenuis, 5 per cent. Festuca rubra and 70 per cent. F. rubra var. commutata. 
primary pathogens and all may well be intestinal in origin having invaded the surrounding tissues secondarily before or after death.

At present, therefore, the cause of more than half the deaths among $M$. jurtina larvæ has yet to be established. Nor do we know whether the micro-organisms responsible for this part of the mortality are in any way selective relative to spotting in the adults.

Compared with previous years, mortality among the pupæ was nearly twice as great. Here again, there is little evidence of the cause

TABLE 2

Summary of samples of reared and flying female M. jurtina from Cheesefoot Head Ig6I (late, flying sample from Yew Hill, see p. ${ }_{51} 6$ )

\begin{tabular}{|c|c|c|c|c|c|c|c|c|c|c|c|}
\hline \multirow{2}{*}{$\begin{array}{c}\text { Reared } \\
\text { or } \\
\text { flying }\end{array}$} & \multirow{2}{*}{ Period } & \multirow{2}{*}{$\begin{array}{l}\text { Date of } \\
\text { emergence }\end{array}$} & \multicolumn{6}{|c|}{ Spots } & \multirow{2}{*}{$\begin{array}{l}\text { Spot } \\
\text { av. }\end{array}$} & \multirow{2}{*}{ Total } & \multirow{2}{*}{ Comparison } \\
\hline & & & 0 & I & 2 & 3 & 4 & 5 & & & \\
\hline Reared & Early & I2.vi-28.vi & I 7 & 28 & $2 I$ & 7 & I & - & $I \cdot 28$ & 74 & $\chi_{(2)}^{2}=5.78 ; P \simeq 0.05$ \\
\hline $\begin{array}{l}\text { Reared } \\
\text { Reared }\end{array}$ & $\begin{array}{l}\text { Middle } \\
\text { Late }\end{array}$ & $\begin{array}{l}\text { 29.vi-21.vii } \\
\text { 22.vii-23.viii }\end{array}$ & $\begin{array}{l}33 \\
33\end{array}$ & $\begin{array}{l}33 \\
11\end{array}$ & $\begin{array}{r}22 \\
9\end{array}$ & $\begin{array}{l}3 \\
3\end{array}$ & 一 & - & $\begin{array}{l}0.95 \\
0.68\end{array}$ & $\begin{array}{l}91 \\
56\end{array}$ & $x_{(2)}^{2}=7.67 ; \quad P \simeq 0.02$ \\
\hline Flying & Early & I8.vi-29.vi & 52 & $4^{2}$ & 29 & I6 & I & - & $\mathrm{I} \cdot 09$ & I 40 & $\begin{array}{l}x_{(3)}^{2}=1.32 ; \\
0.8>\mathrm{P}>0.7\end{array}$ \\
\hline Flying & Middle & 6.vii-15.vii & 62 & $4 \mathrm{I}$ & 30 & II & 2 & - & 0.97 & I 46 & $\chi_{(2)}^{2}=18.38 ; P<0.001$ \\
\hline Flying & Late & 19.viii-22.viii & 103 & 44 & 17 & 2 & - & - & $0.5^{1}$ & 166 & \\
\hline
\end{tabular}

of death which almost invariably took place at the pigmented stage. The fact that in only one instance has an insect parasite been detected, suggests that virus or bacteria must be responsible, probably carried over from the larval stage.

\section{COMPARISON OF REARED AND FLYING ADULTS}

\section{(i) Females}

Spot distributions in reared and flying female $M$. jurtina are summarised in table 2 and the various comparisons between them appear in table 3 .

In general, the pattern of emergence among the reared insects was much the same as in previous years. That is to say, adults appearing early derived mainly from larvæ which had escaped parasitisation, exhibited a higher level of spotting than those emerging later which had been subject to drastic elimination by Apanteles. The large number of larvæ available made it possible to divide the resulting imagines into three categories, instead of only two as in previous years. Reference to table 2 shows that while the distinction between the "early" and " middle" groups just reaches the level of formal significance in a $\chi^{2}$ test, that between "middle" and "late" is well established: even more so for the comparison between "early" and "late", 
which gives $\chi_{(2)}^{2}=17.42 ; P<0.001$. The characteristic changes in spotting throughout the period of emergence are also clearly reflected in the spot-averages.

The adults flying at Cheesefoot Head during the "early" and " middle" parts of the season were of great interest on account of their abnormally high spotting. This was typical of the New English pattern, the number of specimens at o spots being less than 6o per cent. of those showing the 0-, I- and 2-spot condition (Creed, et al., 1959). Such a distribution had not been witnessed in the Winchester district since ${ }_{1956} 6$ when it was characteristic of several localities such as Middleton West and Worthy Down, which conformed with a general

TABLE 3

Comparisons of spot-distribution in reared and fying female M. jurtina

\begin{tabular}{|c|c|c|c|}
\hline & \multicolumn{3}{|c|}{ Reared } \\
\hline & Early & Middle & Late \\
\hline Flying Early & $\begin{aligned} & \chi_{(3)}^{2}= 5.22 ; \\
& 0.2>P>0.1\end{aligned}$ & $\begin{aligned} \chi_{(2)}^{2}= & 1.20 ; \\
& 0.7>P>0.5\end{aligned}$ & $\chi_{(2)}^{2}=7.73 ;$ \\
\hline Flying Middle & $\begin{array}{l}\chi_{(3)}^{2}=8.17 ; \\
0.05>P>0.02\end{array}$ & $\begin{aligned} \chi_{(2)}^{2}= & 1.82 ; \\
& 0.5>P>0.3\end{aligned}$ & $\begin{aligned} \chi_{(2)}^{2}=4.4 \mathrm{I} & ; \\
\mathrm{P} \simeq 0.1 & \end{aligned}$ \\
\hline Flying Late & $\begin{array}{c}\chi_{(2)}^{2}=37.52 ; \\
P<0.001\end{array}$ & $\begin{array}{c}x_{(2)}^{2}=18.07 ; \\
P<0.001\end{array}$ & $\begin{aligned} x_{(2)}^{2}= & 3.85 ; \\
& 0.2>\mathrm{P}>0.1\end{aligned}$ \\
\hline
\end{tabular}

rise in spotting among many other southern English populations of $M$. jurtina. From table 2 it will be seen that, like the reared insects, the spot-values of the flying adults proceeded to fall as the season advanced. Although the difference between the "early" and " middle" samples is not significant, the spot-averages give a clear indication of intra-seasonal variation. A comparison of " middle" and "late" individuals shows an overwhelming difference between them, as does that of " early" and "late" $\left(\chi_{(2)}^{2}=26.02 ; P<0.001\right)$.

Unfortunately, on the I8th July, the Cheesefoot Head locality which had thus far served us so well, was subjected to a catastrophic onslaught by a herd of cattle. In a few days the long grass and flowers were grazed like a lawn and the jurtina population destroyed or dispersed. Thereafter, the collection of further samples of larvæ or adults was out of the question. Luckily, at about the same time as we obtained the "middle" sample from Cheesefoot Head, we also made a large collection from Yew Hill $\left(4 \mathrm{I} / 45^{6265}\right)$, another somewhat similar area of natural chalk downland about $4 \frac{1}{2}$ miles away. The 
samples of males and females from the two places proved to be effectively identical (table 4 ).

There is thus good reason for assuming that the "late" sample which had to be obtained from Yew Hill reflected faithfully the situation that would have existed at Cheesefoot Head. That is to say, the spot-values had fallen abruptly to the typical Old English pattern (specimens at o spots being 6o per cent. or more of the total at o, $\mathrm{r}$, and 2 spots; those at 2 not exceeding the number at 1 spot) which had characterised the jurtina populations of the area during the intervening years since 1956 . Important.confirmatory evidence is provided

TABLE 4

Comparison of samples of male and female M. jurtina from Cheesefoot Head and Yew Hill, $196 \mathrm{r}$

\begin{tabular}{|c|c|c|c|c|c|c|c|c|c|c|c|}
\hline \multirow{2}{*}{ Locality } & \multirow{2}{*}{ Date } & \multirow{2}{*}{ Sex } & \multicolumn{6}{|c|}{ Spots } & \multirow{2}{*}{$\begin{array}{c}\text { Spot } \\
\text { av. }\end{array}$} & \multirow{2}{*}{ Total } & \multirow{2}{*}{ Comparison } \\
\hline & & & 0 & 1 & 2 & 3 & 4 & 5 & & & \\
\hline $\begin{array}{c}\text { Cheesefoot } \\
\text { Head }\end{array}$ & & ㅇ & 62 & $4^{1}$ & 30 & II & 2 & - & 0.97 & 146 & $\chi_{(3)}^{2}=5.31 ;$ \\
\hline Yew Hill & 20.vii-22.vii & $q$ & 42 & $3^{1}$ & 29 & 5 & I & & $1 \cdot 00$ & 108 & $0.2>P>0.1$ \\
\hline $\begin{array}{c}\text { Cheesefoot } \\
\text { Head }\end{array}$ & 6.vii-15.vii & $\sigma^{*}$ & I & - & 23 & 12 & 2 & - & $2 \cdot 37$ & $3^{8}$ & $\chi_{(1)}^{2}=2.30 ;$ \\
\hline Yew Hill & 20.vii-22.vii & $\sigma^{*}$ & - & 5 & 77 & 18 & 8 & - & $2 \cdot 27$ & 108 & $0.2>P>0.1$ \\
\hline
\end{tabular}

by the nearby colony at Worthy Down, where differences between early and late samples of females showed a precisely similar trend.

Reference to table 3 shows that spotting among the reared insects from Cheesefoot Head during the three periods of emergence is in close agreement with that of their flying counterparts. Comparison of the "early" reared and flying females may appear to be unduly weighted by the number of individuals with 3 spots or more. However, even if these are omitted, the difference between them still barely attains the level of formal significance $\left(\chi_{(2)}^{2}=5.12 ; 0.1>P>0.05\right)$.

\section{(ii) Males}

The data for reared and flying male jurtina are summarised in table 5 .

A most striking and unexpected feature of male spotting was its low value during the early part of the emergence-a tendency clearly reflected among both the reared and flying insects. Moreover, comparison of these " early" samples shows their spot-distributions to be similar $\left(\chi_{(2)}^{2}=3.52 ; 0.2>\mathrm{P}>0.1\right)$. This is, in effect, a reversal of the situation in the female, and there is at present no evidence to indicate how it may have been brought about. Since it took place early in the summer, presumably Apanteles cannot have been involved. 
Reference to the spot-averages (table 5) suggests that there may have been a slight decline towards the end of the season, but the differences are not significant. The "middle" and "late" samples are homogeneous and can therefore be combined for the purpose of comparing

TABLE 5

Summary of samples of reared and fying male M. jurtina from Cheesefoot Head, Ig6I (late, flying sample from Yew Hill, see p. ${ }_{5}{ }^{1} 6$ )

\begin{tabular}{|c|c|c|c|c|c|c|c|c|c|c|c|}
\hline \multirow{2}{*}{$\begin{array}{l}\text { Reared } \\
\text { or } \\
\text { Flying }\end{array}$} & \multirow{2}{*}{ Period } & \multirow{2}{*}{ Date } & \multicolumn{6}{|c|}{ Spots } & \multirow{2}{*}{$\begin{array}{c}\text { Spot- } \\
\text { av. }\end{array}$} & \multirow{2}{*}{ Total } & \multirow{2}{*}{ Comparison } \\
\hline & & & o & 1 & 2 & 3 & 4 & 5 & & & \\
\hline Reared & Early & 12.vi-28.vi & 2 & 10 & $5^{8}$ & 7 & 1 & 1 & $1 \cdot 97$ & 79 & $\chi_{(1)}^{2}=6.69 ; \quad P \simeq 0.0 I$ \\
\hline $\begin{array}{l}\text { Reared } \\
\text { Reared }\end{array}$ & $\begin{array}{l}\text { Middle } \\
\text { Late }\end{array}$ & $\begin{array}{l}\text { 29.vi-21.vii } \\
\text { 22.vii-23.viii }\end{array}$ & $\overline{1}$ & $\begin{array}{l}3 \\
3\end{array}$ & $\begin{array}{l}33 \\
26\end{array}$ & $\begin{aligned} 11 \\
8\end{aligned}$ & $\begin{array}{l}4 \\
1\end{array}$ & 二 & $\begin{array}{l}2 \cdot 31 \\
2 \cdot 13\end{array}$ & $\begin{array}{l}51 \\
39\end{array}$ & $\chi_{(1)}^{2}=0.45 ; \quad P \simeq 0.5$ \\
\hline Flying & Early & I8.vi-29.vi & 2 & 17 & II 5 & 28 & 7 & - & $2 \cdot 12$ & 169 & $\chi_{(1)}^{2}=4.55$ \\
\hline Flying & Middle & 6.vii-15.vii & I & - & 23 & 12 & 2 & - & $2 \cdot 37$ & $3^{8}$ & $\begin{aligned} & 0.05>P>0.02 \\
\chi_{(1)}^{2}= & 2.40 ;\end{aligned}$ \\
\hline Flying & Late & 19.viii-22.viii & - & 2 & $8 \mathrm{I}$ & 23 & 3 & - & $2 \cdot 25$ & 109 & $0.2>P>0 . I$ \\
\hline
\end{tabular}

spot-values in reared and flying adults during July and August: $\chi_{(2)}^{2}=0.79 ; \mathrm{P} \simeq 0.7$, indicating a close similarity between them.

\section{THE PATTERN OF EMERGENCE}

The abundance of larvæ in 1961 enabled a more detailed analysis to be made of the pattern of emergence of the adults than had hitherto been possible. The results are presented graphically in fig. I and are

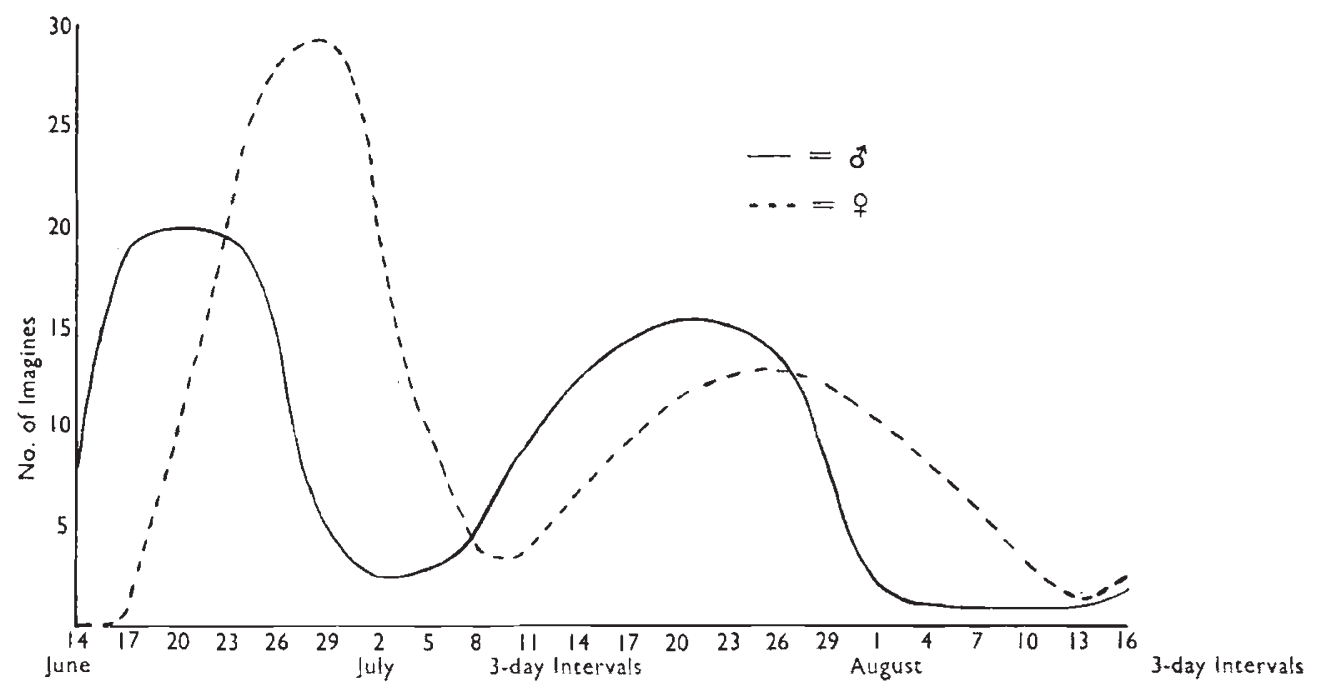

Fic. 1.-Emergence of reared male and female M. jurtina from Cheesefoot Head, 1961 . 
essentially similar in the two sexes. Both exhibited a marked bimodality, the males tending to remain approximately a week in advance of the females. Reference to comparable data from Middleton East over the previous four years reveals similar trends, but these are difficult to analyse in detail owing to the relatively small numbers involved.

The implications of the bimodal emergence in relation to changes in female spotting are of some interest, for it is possible that the life cycle of Apanteles tetricus may be synchronised with larvæ corresponding to the second phase of the emergence but not with those of the first. Thus, the females emerging during the " middle" period (29.vi-2 I.vii) would be expected to exhibit an intermediate form of spotting since they straddled the two phases (table 2).

\section{THE SITUATION AT MIDDLETON EAST IN 1961}

In order to be sure that conditions at Middleton were typical of previous years (Dowdeswell, I96I), an attempt was made to collect larvæ there on I Ith July. Extensive changes had taken place in the ecology of the area, partly owing to the prolonged drought, but chiefly as a result of the great increase in the rabbit population, now recovered from the effects of a severe epidemic of myxomatosis. Thus, more than a third of the area which had once been natural chalk grassland was now reduced to a hard, brittle mat almost totally devoid of the grasses required by jurtina larvæ for food. Collecting under ideal conditions produced only 39 larvæ of which 23 (6o per cent.) subsequently proved to be parasitised. Apparently, the incidence of Apanteles was much the same as it had been in previous years. The emerging adults were too few to be of any value for spot assessment.

Sampling the flying population proved difficult on account of their great rarity, three visits between 8 th and 24 th July producing together only 43 females with a spot-average of $1 \cdot 05$. This accords closely with the values obtaining at Cheesefoot Head (0.97) and Worthy Down (0.9o) during the same period. Evidently the jurtina population at Middleton East was also subject to the wave of high spotting which swept through the district during June and July. A sample of 85 females obtained at Middleton on 30 th August indicated a partial recovery in numbers, the spot-average having now dropped to $0.5 \mathrm{I}-$ its normal level (the spot-average for the previous five years being 0.54 ). Thus in 1961, spotting among the females, which had previously shown such remarkable stability, was subject to the same intra-seasonal variation as characterised other populations in the vicinity; spotaverages at Worthy Down and Yew Hill during late August being 0.55 and $0.5 \mathrm{I}$ respectively.

\section{DISCUSSION}

The results obtained at Cheesefoot Head in I96I show, as at Middleton East, that the Braconid Apanteles tetricus inflicts a heavy 
mortality on those larvæ of Maniola jurtina destined to give rise to imagines from late June onwards. The fact that this period of the emergence is associated with a marked reduction in female spot-values suggests that the parasite may be acting in some way as a selective agent controlling spotting. Stabilisation among the females of the four populations studied in the Winchester district is of great interest in that everywhere spotting was abnormally high during the early part of the summer, exhibiting a typically New English distribution. Morcover, in at least three localities (Yew Hill, Worthy Down and Middleton East), marked intra-seasonal "shift" occurred towards lower, Old English type spot-values later in the season. Such changes

TABLE 6

Comparison of samples of female M. jurtina from Middleton East, 1960 with those from Cheesefoot Head (early) and Yew Hill (late) in $196 \mathrm{r}$

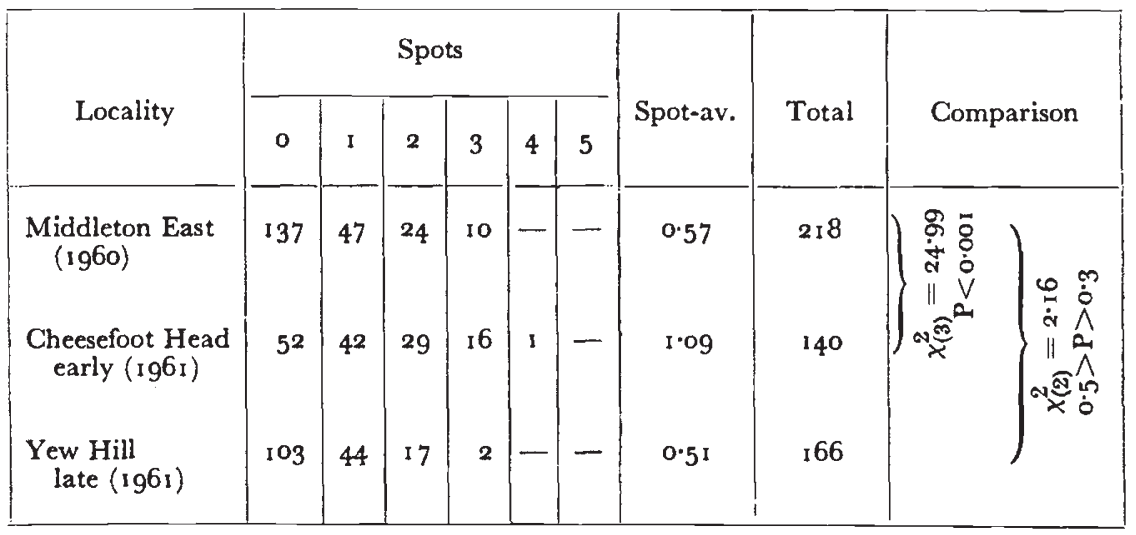

The comparisons here are between Middleton East and Cheesefont Head, and between Middleton East and Yew Hill.

have not previously been observed among any jurtina colonies sampled in the vicinity. Their magnitude is well illustrated when compared with Middleton East in i 960 (table 6) which shows close agreement with the spot-distribution of the late Yew Hill sample in $196 r$.

The fluctuation in female spot-values outlined above accords closely with the observed behaviour of Apanteles which, in $196 \mathrm{I}$, appeared a month later than usual and in somewhat reduced numbers compared with Middleton East in previous years.

These facts provide important supplementary evidence that the principal agent controlling female spotting is Apanteles and not the climate. As I have already shown (Dowdeswell, 1961), in 1959 and I96o insects derived from unparasitised larvæ and emerging early were highly spotted. Those appearing later from larvæ which had suffered a heavy mortality due to Apanteles, exhibited low spot-values similar to wild jurtina. In $196 \mathrm{I}$, the situation among the reared adults was repeated with some indication of continued high spotting until the end of July. The fact that the spot-values of wild females did not assume their normal low level until mid-August (i.e. about a month 
later than usual) is highly suggestive, bearing in mind the late appearance of Apanteles among the reared stocks. We thus have evidence that when $M$. jurtina larvæ are heavily parasitised the female butterflies emerging late have low spot-values, but when they are not high adult spotting persists.

The situation among the males was unexpected in that both the reared and flying adults showed a significant reduction in spot-values during the early part of the season. Such a tendency had not previously been detected in any colony of $M$. jurtina and it is difficult to provide a satisfactory explanation. Judged by the instability of the females, the season 1960-6I must have been a highly abnormal one. On the other hand, it is difficult to see how a reduction in male spotting could be associated in any way with a rise in that of the females because, (a) of the highly significant correlation which has been proved to exist between spot-distribution in the two sexes, the one tending to follow the other when spot-changes occur (McWhirter, 1957): (b) from what we now know of the life cycle of Apanteles, it is unlikely that it could have played a part in bringing about such changes so early in the season.

Analysis of the pattern of emergence among reared $M$. jurtina from Cheesefoot Head, showed it to be bimodal in both sexes (fig. I). Among the females, it is clear that parasitisation by Apanteles was confined mainly to those of the second mode corresponding to the " middle" and "late" periods (table 2) and exhibiting a progressive decline in spot-values. Supplementary but less extensive evidence from the four previous years, suggests that there may be considerable variation both in the relative magnitude and in the times of appearance of the two modes. Sometimes they are roughly of equal size as in 1957, but more often one is larger than the other. Moreover, the interval between them may range from several weeks as in 1960, to only a few days (196I). The latter possibility would explain the situation encountered among samples obtained from certain Devon localities in early August 1961, which were found to contain worn females exhibiting relatively high spot-values characteristic of the first phase, and fresh insects with much lower spotting derived from the second.

\section{SUMMARY}

I. Previous studies at Middleton East, near Andover (Hampshire) have shown that the Braconid Apanteles tetricus inflicts a heavy mortality on larvæ of the butterfly Maniola jurtina. Adult females derived from wild larvæ collected early in the summer, which are mostly unaffected by Apanteles, invariably carry an excess of spots on the underside of the hind wings compared with those appearing later, whose larvæ have suffered a heavy mortality through parasitism.

2. Although no direct causal relationship has yet been established between Apanteles parasitisation and variations in female spotdistribution, statistical evidence derived from Middleton during the 
last four years strongly suggests a connection between them. Spotting in both sexes of $M$. jurtina is a character well known to respond readily to the action of natural selection and to assume a variety of equilibria in different parts of Britain and elsewhere.

3. In $196 \mathrm{I}$, a colony of jurtina inhabiting a different locality at Cheesefoot Head, near Winchester (Hampshire) was investigated in order to test conclusions derived from the previous work.

4. Wild larvæ collected at night and reared in the laboratory under carefully controlled conditions, proved to be subject to much the same level of mortality as those in previous years, partly due to Apanteles and partly to micro-organisms as yet unidentified-probably bacteria.

5. Compared with the previous four years at Middleton, the appearance of Apanteles occurred about a month later than usual and in slightly reduced numbers.

6. Among reared females, the level of spotting underwent the usual changes, being high at the beginning of the emergence and low at the end. This pattern corresponded closely with the behaviour of Apanteles in parasitising the larvæ.

7. Among the flying females at Cheesefoot Head and elsewhere in the district, there was marked intra-seasonal " shift" from high spotvalues at the beginning of the season to lower ones later on.

8. Such a phenomenon had not previously been observed in the Winchester district although it was well known elsewhere. It corresponded closely with the pattern of emergence among the reared females and with the unusually late appearance of Apanteles.

9. Among both reared and flying male jurtina there was a significant deficiency in spotting during the early part of the season. The cause of this is unknown, but it is unlikely to have been due to Apanteles parasitism.

I0. Analysis of the pattern of emergence of $M$. jurtina helps to explain changes observed in the spot-distribution of both reared and flying insects. It also clarifies certain anomalies encountered when sampling populations in the West Country.

II. A sample of larvæ obtained from Middleton East in 196I exhibited parasitisation by Apanteles, typical of previous years and similar to that of the Cheesefoot Head colony.

Acknowledgments.- It is a pleasure to record my gratitude to the executors of the late Captain A. S. Wills for permission to work in Harewood Forest (Middleton East); to Captain the Hon. J. B. Bruce for permitting me to collect at Cheesefoot Head and to Mr. W. T. O. Maidment for allowing me access to the Yew Hill area. The Royal Society has kindly contributed financial help for equipment, while "Shell " Research Ltd. have provided me with a calculating machine. My thanks are particularly due to Dr E. B. Ford, F.R.S., Mr K. G. McWhirter and Mr E. R. Creed for numerous stimulating discussions and helpful suggestions, also for reading the typescript of this paper. Mr G. E. J. Nixon of the Commonwealth Institute of Entomology has kindly checked the identification of Apanteles tetricus. Dr H. M. Darlow of the Microbiological Research Establishment, Porton, has investigated bacterial infection in $M$. jurtina larvae and made valuable suggestions for future 
work. Mr C. F. Rivers of the Agricultural Research Council, Virus Research Unit, has examined dead larvx for virus infection.

To the many helpers who have assisted with the collection of larvac and adults $I$ extend my most grateful thanks. In particular, I would like to thank my laboratory assistants $\mathrm{Mr} \mathrm{A}$. S. Mitchener and $\mathrm{Mr} \Lambda$. J. Lewington for their expert hclp, also members of my family, and J. A. Fcll and H. N. A. Willcox of Winchester College.

\section{REFERENCES}

CREED, E. R., DOWDESWELL, W. H., FORD, E. B., AND MCWHIRTER, K. G. I959. Evolutionary studies on Maniola jurtina : the English mainland, 1956-57. Heredity, 13, 363-39 I.

DOWDESWELL, W. H. I961. Experimental studies on Natural Selection in the butterfly, Maniola jurtina. Heredity, 16 , 39-52.

mCWhirter, K. G. 1957. A further analysis of variability in Maniola jurtina. Heredity, II, 359-37I.

\section{ADDENDUM}

Received 27.viii.62

Results obtained in 1962 from Cheesefoot Head accord closely with those described above for ig6r. Once again, the emergence of reared adults was characteristically bimodal in both sexes. As before, the males showed a tendency towards increased spotting in the middle of the season which declined later on. An unusual feature of Apanteles infestation was that it accounted for I I. 5 per cent. of early larval mortality ( 3.5 per cent. in $196 \mathrm{I})$ in addition to its usual high incidence later on. This increase could explain the somewhat reduced level of spotting among female jurtina emerging early (spot-average $\mathrm{I} \cdot \mathrm{O}$ as opposed to $\mathrm{I} \cdot 28$ in $\mathrm{I} g 6 \mathrm{I}$ ) and the absence of a " middle" phase (see p. 515). As in 1961, female spot-values in both reared and flying insects dropped abruptly from late July onwards, corresponding to the period of maximum Apunteles parasitisation of the larvæ. 